\title{
ピーマンの結実肥大に及ぼす蛍光灯連続光と暗期中断の影響
}

\author{
栘田正治 ${ }^{1} \cdot$ 荻野知子 $^{1} \cdot$ 村上賢治 $^{1} \cdot$ 吉田裕一 $^{1} \cdot$ 向阪信一 2 \\ 1 岡山大学農学部 700-8530 岡山市津島中 1-1-1 \\ ${ }^{2}$ 松下電工株式会社・照明分社・照明戦略企画室 571-8686 大阪府門真市門真 1048
}

\section{Fruit Set and the Development of Peppers as Affected by a Daily Dark Break of Continuous Fluorescent Illumination}

\author{
Masaharu Masuda ${ }^{1}$, Tomoko OGINO ${ }^{1}$, Kenji Murakami ${ }^{1}$, \\ Yuichi YoshIDA ${ }^{1}$ and Shinichi KosAKA ${ }^{2}$ \\ ${ }^{1}$ Faculty of Agriculture, Okayama University, 1-1-1 Tsushima-naka, Okayama 700-8530, Japan \\ ${ }^{2}$ Matsushita Electric Works, Ltd., 1048 Kadoma, Osaka Prefecture 571-8686, Japan
}

\begin{abstract}
The objective of this experiment was to clarify the effect of a daily $4 \mathrm{~h}$-dark break of continuous light to decrease the input-energy in pepper fruit production, cv. Kyo-midori. Plants were grown in a closed environment for 10 months in half-strength "Otsuka- $A$ " nutrient solution $\left(\mathrm{EC} 1.4 \mathrm{dS} \mathrm{m}^{-1}\right)$, in which the additional solution $\mathrm{pH}$ was adjusted to $\mathrm{pH} 5.6$, with a range of continuous light intensity between 150 and $350 \mu \mathrm{mol} \mathrm{m}^{-2} \mathrm{~s}^{-1}, 800 \mathrm{ppm} \mathrm{CO}_{2}$-enrichment, a constant temperature of $27^{\circ} \mathrm{C}$ and ambient humidity. The continuous light treatment was continued for 2 months from the beginning of first flowering (1st period), and the subsequent treatment of a daily $4 \mathrm{~h}$-dark break was carried out for 2 months (2nd period), and alternative treatments of continuous light and a daily $4 \mathrm{~h}$-dark break were continued.

Green pepper fruit was harvested at marketable size about 20 days after flowering. At the end of each 2 month period, the remaining solution was renewed, and all the fruit on the plant was removed.

The number of harvested fruits over 2 months increased with plant growth. The cumulative pattern of harvested fruit in the daily $4 \mathrm{~h}$-dark treatments (2nd and 4 th periods) did not differ from that obtained before and after the continuous light treatment (1st, 3rd and 5th periods). The electrical conductivity $(\mathrm{EC})$ of the remaining solution fluctuated in the range of 1.2 and $3.5 \mathrm{dS} \mathrm{m}^{-1}$, and $\mathrm{pH}$ in the range of 6.0 to 7.8 . The plants grew vigorously without any symptoms of physiological disorder.

When compared to greenhouse peppers harvested in late spring, those under artificial light had 2 times higher chlorophyll and carotinoid content in the fruit skin. No difference was found between continuous light and the dark break.

From these results, a daily $4 \mathrm{~h}$-dark break produce no problems in fruit yield and quality, and it contributes in reducing input-energy in pepper fruit production.
\end{abstract}

Keywords : pepper fruit production, dark break of continuous illumination, chlorophyll, carotinoid 
に見られるような生理障害を全く発現せず正常に生育し 結実肥大する5)。ピーマンの連続光下での乾物生産は, 炭酸ガス $800 \mathrm{ppm}^{6}$, 光強度 $300 \mu \mathrm{mol} \mathrm{m}^{-2} \mathrm{~S}^{-1}$ 付近で最 高となる7). また, 炭酸ガス濃度や光強度をさらに高め ると葉にクロロシスが発現しやすくなる事がわかってい $ろ^{6,7)}$. 光強度を上げても暗期を適当な時間挿入すれば ピーマンに限らず, ナス, トマトでも正常に生育するこ とは, その条件がより自然な明暗サイクルに近づくこと から容易に理解できる。しかし，人工光強度を上げると， 室内の冷却に膨大なエネルギーを要することになる。こ のエネルギーを極力少なくする意味で, われわれの一連 の研究 ${ }^{5 \sim 7)}$ では光源に蛍光灯を用(光量は連続光とする ことで不足分を補扔うと考えてきた。 しかるに, 蛍光灯 の場合でも暗期挿入が結実肥大に積極的な効果をもたら すか，あるいは，暗期挿入が結実肥大にマイナス効果を もたらさなければ，暗期は経済栽培を考える上で意味を 持つことになる.

既報)において 12 時間の明暗サイクルではピーマン は開花するものの，ほとんど結実しないことが明らかと なっていることから，本論では，24 時間を単位とした 時の結実肥大に及济す 4 時間暗期挿入の影響を調查した. また，収穫果実のクロロフィル含量とカロチノイド含量 を自然光下の同型水耕システムで収穫した果実のそれと 比較した。

\section{材料および方法}

\section{1. 連続光と 4 時間暗期中断下での生育と果実収量}

ピーマン (Capsicum annumm L.) ‘京みどり’を, バー ミキュライトを入れたプラスチックトレイに播種し，温 度 $28^{\circ} \mathrm{C}$, 暗黒条件下で発芽させた。発芽後, 温度 $28^{\circ} \mathrm{C}$, 相対湿度 $70 \%$, 蛍光灯 $150 \mu \mathrm{mol} \mathrm{m} \mathrm{m}^{-2} \mathrm{~s}^{-1}$ を用いて 24 時 間日長(連続光) に設定した人工気象室(日本医理化, NKsystem BIOTORON NC350) 亿移した。灌水を大塚 $\mathrm{A}$ 処方 $1 / 2$ 濃度培養液ミリ $\mathrm{mol}$ 単位 $\left(\mathrm{NO}_{3}-\mathrm{N} ; 8.0\right.$, $\mathrm{NH}_{4}-\mathrm{N}$; 0. 85, P; 0.85, K; 3. 8, Ca; 2. 05, Mg; 0.925, $\mathrm{S} ; 0.925) て ゙ 2$ 日に 1 回行った。 子葉展開時にミニロッ クウール $(2 \times 2 \times 2 \mathrm{~cm}) へ$, 第 2 本葉展開時にロックウ 一ルキューブ $(7 \times 7 \times 5 \mathrm{~cm})$ に移植した。本葉が $6 \sim 7$ 枚 展開した時(播種後 35 日) に温度 $28^{\circ} \mathrm{C}, \mathrm{CO}_{2}$ 濃度 800 ppm に設定した蛍光灯連続光 (定植時草冠の光強度 150 $\mu \mathrm{mol} \mathrm{m} \mathrm{m}^{-2} \mathrm{~s}^{-1}$, 生育するにつれて高まり最終的には 350 $\left.\mu \mathrm{mol} \mathrm{m}{ }^{-2} \mathrm{~s}^{-1}\right)$ 下の人工気象室 $(2.6 \times 1.7 \times 2.2 \mathrm{~m})$ に定植 した。供試本数は 3 株で， 2 個のロックウールスラブ $(90 \times 30 \times 10 \mathrm{~cm})$ に植物体を 3 株植え，ロックウールス
ラブの表面をシルバーポリで覆った。貯液タンクには, 前報8に準じてリン酸により $\mathrm{pH}$ を 5.6 に調整した大塚 八ウス $1 / 2$ 濃度を入れた。還流ポンプを定植時には 1 日 に 4 回, 定植後 4 か月からは 1 日に 16 回, 15 分間稼動 させることにより養液を循環させた。貯液タンクの水量 が約 $1 / 4$ になった頃に当初の培養液を補充した。 $2 \sim 3$ 日㧍きに手で植物体を振動させ受粉を促した。

定植後 2 週間毎に残存培養液をサンプリングし, $\mathrm{pH}$ と電気伝導度 $(\mathrm{EC})$, 無機成分 $\left(\mathrm{NO}_{3}-\mathrm{N}, \mathrm{P}, \mathrm{K}, \mathrm{Ca}, \mathrm{Mg}\right)$ を測定した。 P はバナドモリブデン酸法, $\mathrm{NO}_{3}-\mathrm{N}, \mathrm{K}$, $\mathrm{Ca}, \mathrm{Mg}$ はイオンクロマトグラフにより測定した。また, 週に 2 回, 開花後約 20 日前後を目安に肥大が止まった 果実を収穫し, 果実の生体重と尻腐れ果の発生率につい て調查した。

単一の栽培装置で長期にわたって植物体の生育反応を 調べるために， I 期を 2 か月として第 $\mathrm{V}$ 期までの 10 か 月間栽培を行った。第 1 番花の開花時から 2 か月毎に連 続光区間と 4 時間暗期挿入区間を交互に設定し，暗期挿 入の影響を推定した。光条件を変えた時点で貯液槽に残 っている培養液を捨て, 新しい養液を加えて 20 分程度 循環させた後に再度捨て, 新しい養液を満たした。この 時, 果実は子房の肥大が認められた幼果も含め, すべて 取り除いた。

\section{2. 人工光下と自然光下における果実の色素含量の比較}

蛍光灯連続光下で収穫したピーマン果実と自然光下の ハウス内で収穫した果実の色素含量を比較すると同時に 4 時間の暗期挿入が果実の色素含量にどのような影響を 及ぼすかを調査した。これには，第 I，II，III, IV，V期 に収穫した果実を供試した。クロロフィルの分析には ピーマン果皮 $10 \mathrm{~g}$ を細かく切り，そこから $5 \mathrm{~g}$ を乳鉢にと り $2.5 \mathrm{~g}$ の海砂と約 $20 \mathrm{~m} l$ のアセトンを加えて磨砕ろ過 し，残渣の緑色が無くなるまで数回アセトンを加えて抽 出を繰り返した。抽出液は $80 \mathrm{~m} l$ に定容し分光光度計 (島津 UV-160A)により $645 \mathrm{~nm}$ と $663 \mathrm{~nm}$ の吸光度を測 定した9)。また，カロチノイドの定量は，上述のアセト ン抽出液のうち $20 \mathrm{~m} l$ をナス型フラスコにとり減圧下で アセトンを蒸発させ，残渣を $10 \% \mathrm{KOH}-\mathrm{EtOH}$ に溶解 したあと, へキサンで数回分取し，無水硫酸ナトリウム で脱水後, 定容し $450 \mathrm{~nm}$ の吸光度を測定した。総力口 チノイド量は $\gamma$-カロチン量として算出したが，その值 は， $\mathrm{n}$-ヘキサン溶液 $1 l$ 中に $1 \mathrm{mg}$ の $\gamma^{-}$カロチンが存在 すると, その溶液の吸光度は 0.25 となるので, この既 知の值を用いて換算した。 


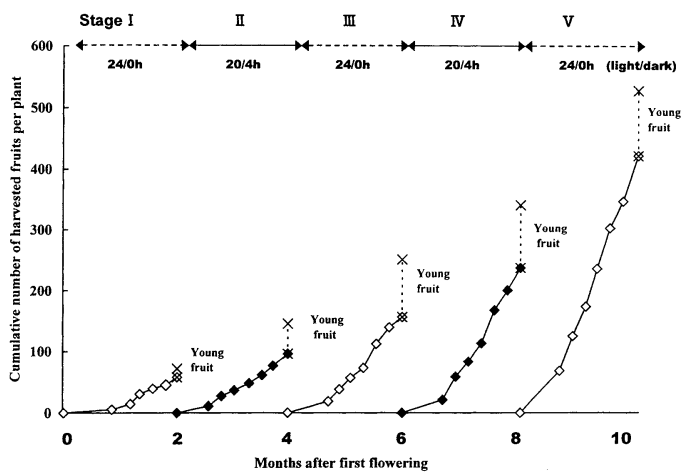

Fig. 1 Cumulative pattern of harvested fruits as affected by continuous lighting $(\diamond)$ and a daily 4h-dark break

$\times \cdots--\times$ Young fruits at pre-harvesting stage

\section{結果および考察}

\section{1. 連続光と 4 時間暗期中断下での生育と果実収量 果実収量}

播種後 42 日で第 1 花が開花し, 果実は播種後 62 日で (開花 20 日)で収穫できるほどの大きさに達した。この 10 か月間での総収穫果数は株当たり平均 990 個, 総収 穫果重量は $14 \mathrm{~kg}$ とった。 なお，幼果も含めると株当 たり 1340 個となった (Fig. 1 累積収穫果実総数).

ピーマンの 2 か月毎の累積収穫果数をみると 4 時間暗 期を挿入した第 II 期，第 IV 期ともに収量はそれらの 前後に設定した 24 時間連続光区での収量の増加パター ンと比べ大きな変化を示さなかった(Fig. 1).これは, 連続光耐性のピーマンでさえ 4 時間の暗期は連続光 250 $\mu \mathrm{mol} \mathrm{m} \mathrm{m}^{-2} \mathrm{~s}^{-1}$ 付近で維持された個体の光合成能をわずか に高めていることを意味する. このことと, 光強度を $120 \mu \mathrm{mol} \mathrm{m} \mathrm{m}^{-2} \mathrm{~s}^{-1}, 12$ 時間の明暗サイクルではピーマン は開花してもほとんど結実しない5)ことを考え合わせる と, ピーマンにおける乾物生産の最適光強度は暗期の長 さによって決定されると推察される。したがって, 暗期
の長さを可変変数 $(\infty)$ として乾物生産の最適光強度を求 めることにより，ピーマンの潜在的生産能力を知ること ができると考えられる. 本システムでは, 光強度が制限 要因となることから，その範囲内で経済的組み合わせを 採用することになろう。

\section{生充様相}

茎の伸長は生育後期になるほど抑制され，単位期間当 たりの節数も少なくなった，節間は当初から短く平均 $2.2 \mathrm{~cm}$ で, III 期以降は $1.6 \mathrm{~cm}$ とさらに短縮した. 果重 は生育後期になるほど小さくなったが, 果実の乾物率は 高まった。果実の尻腐れ率は連続光区の第 I 期が 25\% と高かったが，その後の期ではほとんど発生しなかった (Table 1).

\section{培養液変動}

残存培養液の $\mathrm{pH}$ は連続光, 4 時間暗期挿入に関係な く6.0〜 7.8の間で推移した(Fig. 2). 残存培養液の EC も連続光， 4 時間暗期挿入に関係なく, 生育前期には 徐々に低下し, 生育後期には上昇した. なお, 定植後 4 か月の時点で $\mathrm{EC}$ が $1.0 \mathrm{dSm}^{-1}$ 前後にまで低下したため, 添加培養液を $1.8 \mathrm{dSm}^{-1}$ に上げたところ, それ以降に EC は急速に上昇した. そこで，ひと月半のちに再び添 加培養液を $1.4 \mathrm{dSm}^{-1}$ に戻したところ，1.6〜2.6

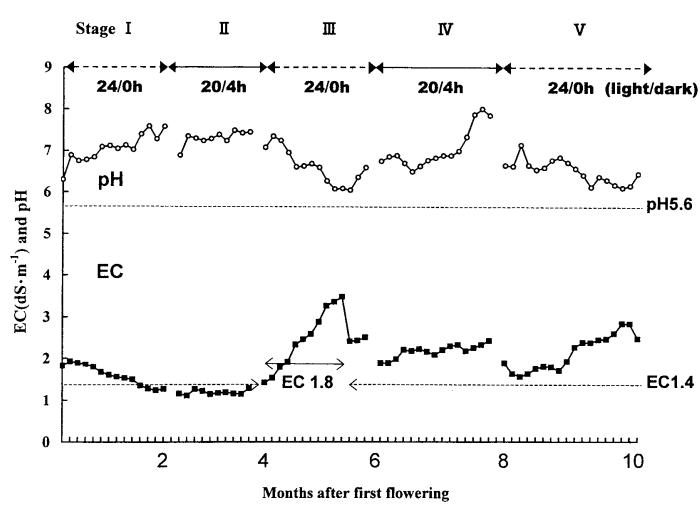

Fig. 2 Changes in electrical conductivity (EC) and $\mathrm{pH}$ in remaining nutrient solution

Table 1 Effect of a daily 4 h-dark break on vegetative growth, fruit development and incidence of blossomend rot.

\begin{tabular}{ccccccccc}
\hline \hline & & \multicolumn{3}{c}{ Growth of main shoot } & Fresh weight & \multicolumn{2}{c}{ \% of } & \multicolumn{2}{c}{\begin{tabular}{c} 
blossom-end \\
per \\
\cline { 3 - 5 } Stage
\end{tabular}} & $\begin{array}{c}\text { Light/dark } \\
\text { (h) }\end{array}$ & $\begin{array}{c}\text { Length } \\
(\mathrm{cm})\end{array}$ & $\begin{array}{c}\text { Number } \\
\text { of node }\end{array}$ & $\begin{array}{c}\text { Internode } \\
\text { length }(\mathrm{cm})\end{array}$ & $\begin{array}{c}\text { fry matter } \\
\text { in fruit }(\mathrm{g})\end{array}$ & $\begin{array}{c}\text { rot } \\
(\%)\end{array}$ \\
\hline I & $24 / 0$ & 37.5 & 17.3 & 2.2 & 24.6 & 7.4 & 24.9 \\
II & $20 / 4$ & 33.8 & 16.8 & 2.0 & 16.7 & 6.6 & 0.0 \\
III & $24 / 0$ & 22.4 & 14.2 & 1.6 & 16.3 & 7.7 & 0.0 \\
IV & $20 / 4$ & 17.8 & 11.2 & 1.6 & 13.7 & 8.4 & 0.1 \\
V & $24 / 0$ & 11.2 & 6.4 & 1.6 & 13.8 & 8.6 & 0.1 \\
\hline
\end{tabular}




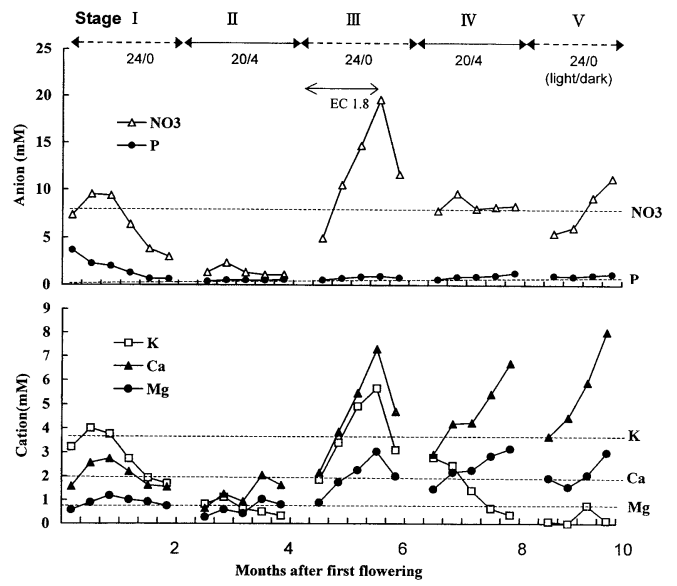

Fig. 3 Changes in cation and anion concentration in remaining nutrient solution.

$\mathrm{dSm}^{-1}$ の範囲内でかなり安定して推移した。

残存培養液の硝酸態窒素濃度は EC 值と対応して, 生 育前期には低下する傾向にあり, 生育後期には徐々に上 昇した Fig. 3)。リン濃度は定植直後に添加培養液より もはるかに高くなったが, これはロックウールスラブか らリンが浸出したことによる. その後, リンは生育期間 を通して低い濃度で推移した。 カリウム，カルシウム， マグネシウムの濃度も生育前期には低く推移し, 生育後 期には上昇した。しかし，カリウムの濃度だけは常に減 少する傾向にあった. なお, アンモニア態窒素は検出さ れなかった，以上のように，培養液の $\mathrm{pH}$ ならびに成分 濃度の変動には 4 時間暗期挿入の影響がほとんど認めら れず，それら変動パターンは管理法が同様である前報 ${ }^{8)}$ とほぼ類似したことから(ただし，EC1. $8 \mathrm{dSm}^{-1}$ 区間を 除く)培養液は大塚 $\mathrm{A}$ 処方 $1 / 2$ 濃度, リン酸で $\mathrm{pH} 5.6$ に調整して栽培を行えばよいと考えられた。

\section{まとめ}

連続光に 4 時間の暗期を挿入しても収穫果数の増減パ ターンに大きな変動はみられず果実の尻腐れ率にも影響 が現れなかったことから，4 時間暗期の挿入は投入工ネ ルギーの低減化に貢献できるものといえる，なお尻腐れ 率は定植值後だけに多発したが，この原因については今 後検討を要する。

\section{2. 人工光下と自然光下における果実の色素含量の比較}

果実中のクロロフィル含量, カロチノイド含量ともに 人工光下で栽培した果実の方が自然光下で栽培した果実 よりも有意に高く約 2 倍となった(Fig. 4). しかし，人 工光下で栽培した果実においては連続光区と 4 時間暗期 挿入区で差は認められなかった。

自然光下のハウス栽培では温度, 湿度, $\mathrm{CO}_{2}$ 濃度な
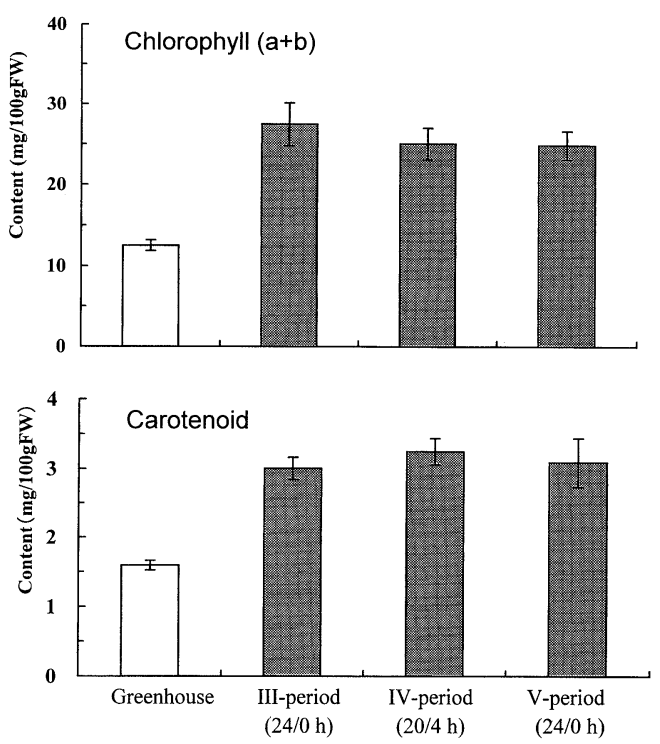

Fig. 4 Chlorophyll and carotenoid contents in pepper fruits harvested in natural and artificial light environments.

どの環境が刻々と変化するのに対し，人工光下の栽培で はそれら環境はほぼ一定に制御されている。このように 自然光下の環境はすべてが変化するため，環境の影響を 個別に人工光下のそれと比較することは不可能といえる. したがって，自然光空間と人工光空間といった一般概念 のもとに比較して次のように言えるであろう。つまり， 環境が一定に制御された人工光下のピーマン果実は自然 光下の果実よりもクロロフィル含量, カロチノイド含量 とも 2 倍近く高まる.今後は, さらなる収量の増大手法 を探りつつ, 収穫果実の脂質成分, ポリフェノールさら にはビタミン Cやビタミン E など機能性成分について も比較検討する必要がある。

\section{摘 要}

蛍光灯連続光下でのピーマンの長期栽培の最適条件を 明らかにする研究の一環として，24 時間を単位とした 時の着果と肥大に及ぼす 4 時間暗期挿入の影響を調査し た。

ピーマン“京みどり’を蛍光灯連続光(光強度 $150 \mu \mathrm{mol}$ $\left.\mathrm{m}^{-2} \mathrm{~s}^{-1}\right)$ で育苗し, 光強度 $150 \sim 350 \mu \mathrm{mol} \mathrm{m} \mathrm{m}^{-2} \mathrm{~s}^{-1}$, 温度 $27^{\circ} \mathrm{C}, \mathrm{CO}_{2}$ 濃度 $800 \mathrm{ppm}$ に設定した人工気象室内の口 ックウールに定植した。第 1 番花開花時から約 2 か月毎 に第 I 期から第 $V$ 期までに分け，連続光区と 4 時間暗 期挿入区を交互に設定し，10 か月栽培を行った。また， 
蛍光灯連続光下で育苗した苗をガラス室に設置したロッ クウールに定植し自然光下の果実品質を人工光下のそれ と比較した。

2 か月毎の累積収穫果数は生育が進むにつれて増加し た。暗期を挿入した第 II 期, 第 IV 期ともに収量はそ れらの前後に設定した 24 時間連続光区での収量の増加 パターンと比べ大きな変動は示さなかった。果実の尻腐 れ率は連続光の第 I 期で $25 \%$ と高かったが，その後は ほとんど発生しなかった。残存培養液の $\mathrm{pH}$ は連続光, 暗期挿入に関係なく 6.0 ～ 7.8 の間で推移した. EC も 連続光, 暗期挿入に関係なく, 生育前期には低下傾向を 示し，生育後期には上昇傾向を示した．この EC に対応 して硝酸態窒素, カリウム, カルシウム, マグネシウム の濃度は生育前期には低く推移し生育後期には徐々に上 昇した。しかし, カリウム濃度は常に減少した。リン濃 度は $\mathrm{pH}$ 調整( $\mathrm{pH} 5.6)$ に用いた正リン酸にも影響され， 生育期間を通して当初の設定値近い濃度で推移した。

人工光下で栽培した果実はクロロフィル含量, カロチ ノイド含量ともに自然光下で栽培した果実の 2 倍を示し た. 24 時間連続光で栽培した果実と 4 時間暗期插入で 栽培した果実間に違いはなかった。

以上の結果より，ピーマン“京みどり’は 4 時間の暗期 を挿入しても果実収量の減少をきたさないものと考えら れ, 果実の色素含量, つやなどにも影響が出なかったこ とから，4 時間暗期の挿入は投入エネルギーの低減に貢 献できるものといえる.

\section{謝辞}

本研究は, 文部科学省科学研究費「基盤研究 (B)- (2) 課題番号-11556006」によって行われたもので記して感 謝の意を表す。

\section{引用文献}

1) Murage, E. N., Sato, Y. and Masuda, M. : Relationship between dark period and leaf chlorosis, potassium, magnesium and calcium content of young eggplants, Scientia Hortic., 66: 9-19 (1996)

2) Murage, E. N., Watashiro, N. and Masuda, M. : Leaf chlorosis and carbon metabolism of eggplant in response to continuous illumination and carbon dioxide, Scientia Hortic., 67: 27-37 (1996)

3) Withrow, A. P. and Withrow, R. B. : Photoperiodic chlorosis in tomato, Plant Physiol., 24 : 657 -663(1949)

4) Hillman, W. S. : Injury of tomato plants by continuous lighting and unfavorable photoperiodic cycles, Amer. J. Bot., 27 : 87-97 (1956)

5) Masuda, M. and Murage, E. N. : Continuous fluorescent illumination enhances growth and fruiting of pepper, J. Japan. Soc. Hort. Sci., 67 : 862-865(1998)

6) 栘田正治, 吉田裕一, 村上賢治, 浜田優子, 向阪 信一: 蛍光灯連続光下でのピーマンの結実肥大に 及注す炭酸ガス施肥効果, 植物工場学会誌, 12 (4) : 254-260 (2000)

7）栘田正治, 山口朋之，村上賢治：ナスとピーマン の乾物生産扔よび葉の光生理障害と SOD 活性に 及ぼす連続光強度の影響, 植物工場学会誌, 14 (1) : 32-37 (2002)

8）栘田正治, 山口朋之, 尾崎真紀, 村上賢治, 吉田 裕一, 向阪信一: 蛍光灯連続光下でのピーマン栽 培に扔ける循環培養液の濃度・組成および $\mathrm{pH}$ の 変化とその管理, 植物工場学会誌, 13(3)：192198 (2001)

9) Arnon, D. I. : Copper enzymes in isolated chloroplasts. Polyphenoloxidase in Beta vulgaris. Plant Physiol., 24 : 1-15(1949) 